This paper is a post-print of an article published in Australian Journal of Political Science

36(1) 2001: 7-26. The definitive version is available at:

http://www.journalsonline.tandf.co.uk/(rfr54k55qkj0hx55leojqr45)/app/home/contribution.asp?referrer=parent\&

backto=issue, 1,11;journal,19,34;linkingpublicationresults, 1:100642,1

\title{
A Problematic Discipline: The Identity of Australian Political Studies
}

\author{
Michael Crozier * \\ University of Melbourne
}

\section{ABSTRACT}

Political science as a distinct discipline only emerged in the Australian academy after World War II. By the end of the 1950s it was attracting thousands of undergraduates. Into the 1990s and beyond, political science has remained a relatively 'successful' discipline. However it would be difficult to argue that the identity of Australian political science has been forged by disputes over the 'scientific' core of the discipline. Some Australian political scientists have claimed that this deficit is a fundamental weakness, denying the discipline both a set of common professional values and a basis for the integration of research. By contrast, this paper will argue that the issue of identity is better considered from a historically sensitive perspective rather than purely in terms of profession and methodology.

'Political science must be problematic'

P.H. Partridge (1957)

\section{Introduction}

The year 2002 will mark the fiftieth anniversary of the founding of the Australasian Political Studies Association (APSA). For some the event will offer an occasion for celebration, for others perhaps a sigh of indifference. The sense of enthusiasm for professional identity among those engaged in political studies in Australia has always been mixed. Even the designation of the 'discipline' — political studies, political science, government, politics - is equally varied, in some cases due to pure accident, in others to a deliberate statement of orientation. Whether these have been limiting factors is a moot point. Significant work has been done across the general field by scholars quite untroubled by nomenclature or untouched by a need to huddle professionally. There have been various attempts to identify some common province for Australian political studies. Yet these efforts have tended to emphasize differences rather than develop a sense of consonance. Nonetheless, notable political research continues to be produced and courses of study in politics remain attractive to large numbers of students (Zetlin 1998,192-3). On the face of it, this is suggestive of a fundamental disjuncture between disciplinary identity and the ongoing practice of political studies in Australia. The profile of the professional association would seem to confirm this to the extent that it is has not had a strong role in demarcating the field of inquiry, defining disciplinary coherence, or even gatekeeping professional practice. 
Attempts to redress this situation have usually generated swift resistance often rooted in a suspicion of professionalisation as narrow specialisation. ${ }^{1}$ However what if efforts at professional self-organisation are bracketed out of the equation? As it is, a good deal of Australian political studies continues on regardless of formal professional activity. In part, this under-professionalisation distinguishes the Australian case from the North American experience. Yet the same fact also tends to mark political studies out as an exception among the other major social sciences (and humanities) in Australia. The most obvious counter example is Australian economics, which mirrors the profile of its American counterpart with a clear disciplinary coherence and a strong professional identity. But this contrast should not distract from the wider development of the social sciences in Australia. Pertinent to the story of Australian political science is the rise of economics to pre-eminence among the Australian social sciences and its central role in Australian public policy since the late 1920s (Bourke 1988; Brown 1997; Crozier 2000; Fleming 1995). While the hard-boiled economists may prefer to ignore this history in favour of a whiggish triumphalism resting on 'rigorous methodology,' the reception and proliferation of this methodology cannot be adequately accounted for without reference to the historical background. In general terms, this is arguably even more the case in regard to Australian political studies given its methodological eclecticism and low levels of professionalisation.

These preliminary remarks suggest the need to address the identity issue with some sensitivity to the history of the discipline's practice and context. From this perspective the notion of 'discipline' may lose some of its strong prescriptive resonances, especially in regard to methodology, though not necessarily its descriptive power. This paper explores some of the possibilities availed by this approach and considers what it may offer in terms of the identity of Australian political studies and its future directions.

\section{Orienting the Puzzle}

The puzzle of identity can be first considered by detailing some of the assumptions underlying one of the most trenchant critiques of Australian political studies (Sharman1985, 111-112). This analysis laments the condition of Australian political studies, reading its eclecticism as a sign of general confusion about its disciplinary task. It describes political science in Australia as an indeterminate practice more concerned with normative theory and advocacy than the systematic analysis of political and social phenomena. Its claim is that what passes for political science is merely cobbled together from other social sciences and humanities, with nothing distinctive about how it analyses and explains political issues. But this lament is also driven by a specific preconception of disciplinary identity that places singular importance on core problems and common methodologies. From this perspective, Australian political studies is deemed to lack disciplinary coherence and thus in need of some kind of conceptual and methodological consolidation. In part, this critique credits the Australia malaise to the lack of North American style graduate programs of course work and comprehensive examinations. The failure of Australian practitioners to keep up with developments in American political science is also cited as a contributing factor. Australia did not experience a behavioural

\footnotetext{
* For comments and suggestions thanks to Peter Beilharz, Ann Capling, Mark Considine, John Dryzek, Sol Encel, Brian Galligan, Jack Gunnell, Peter Katzenstein, Marian Sawer and the anonymous referees. Thanks to Zora Simic for research assistance. Research for this paper was funded from a Large Australian Research Council Grant (no: A79803328) on the social sciences and nation building in Australia.

${ }^{1}$ It is a regular occurrence at the Annual General Meeting of the Australasian Political Studies Association for the question of disciplinary identity to be invoked (or provoked), usually around the issue of whether political studies is a social science or part of the humanities. The debate is ongoing.
} 
revolution and therefore there was 'no self-conscious grappling with the question of what political science is really about.' Consequently the Australian discipline has limped along as an assortment of vaguely related individual endeavours, lacking the critical mass that could generate distinctive schools.

Obviously this critique of Australian political studies takes the American case as the exemplary model. However the use of this case as the critical standard lacks a degree of finesse. First, there seems to be an assumption that American political science is unproblematic vis-à-vis disciplinary identity. But does this oversimplify a more complicated story? Just how coherent is the American discipline in terms of a scientific core? Second, Australian practice may be different to American practice but is a straightforward comparison sufficient to evaluate Australian political studies? Consideration of the first set of queries will help to clarify the second.

In the heartland of conventional political science in the United States there has been an ongoing debate about the essential character of the discipline. While the American APSA plays a far more substantial role in the professional practice of political science than the Australasian APSA, it nonetheless continues to be troubled by questions of disciplinary coherence. In 1968 David Easton (1968) lamented that political science was a discipline still in search of an identity. ${ }^{2}$ Construed as a scientific core, this quest remains unfulfilled. The proliferation of areas of investigation and modes of inquiry since Easton's famous exhortation would also suggest that this search is less and less likely to succeed. On the other hand while growing diversity may indeed enrich the general field of inquiry it does beg questions about mutual compatibility and common intellectual enterprise. Has the field of political inquiry become so diverse that it is now difficult or meaningless even to speak of a 'common enterprise'? In any case, does it matter if an incommensurate pluralism reigns? And what kinds of implications does this predicament hold for political inquiry in terms of the social sciences (and humanities), the broader academic community, and society more generally? In the contemporary age of 'interdisciplinarity' these kinds of questions are hardly inimitable to political studies. Nonetheless this does not preclude an examination of the specific predicament of political studies.

Recent American debate on the identity question has incorporated direct reference to the role of disciplinary history (Almond 1990, 13-31; Easton, Gunnell and Graziano 1991; Farr and Seidleman 1993; Farr, Dryzek, Leonard 1995; Easton, Gunnell, Stein 1995; also see Wæver 1998, 690-696). Of particular note is a contentious essay by John Dryzek and Stephen Leonard first published in the American Political Science Review in 1988 (Dryzek and Leonard 1995). Dryzek and Leonard draw together the issues of identity and disciplinary history, casting them into sharp analytical focus, drawing insights from post-empiricist philosophy of science while differentiating the 'objects' of political science from those of natural science. Their aim is to critically challenge whiggish accounts of political science,

\footnotetext{
${ }^{2}$ However it should be registered that by this time Easton's position had shifted from his earlier strong advocacy of the behavioral revolution. Indeed, in the late 1960s Easton - along with others like Sheldon Wolin - was concerned with the hiatus between political science and contemporary political issues. In his 1969 APSA address Easton declared a new era for political science, a 'post-behavioral revolution' in the discipline arising from disaffection with its pure 'scientific' aspirations. Without in any way suggesting that analytical rigour be forsaken, he urged the need for the discipline to attend to the pressing political problems of the day. John Gunnell notes that this echoed a long tradition in which social science projects an integral role for itself in the shaping of public life (see Gunnell 1993, 16-17).
} 
targeting in particular those that discount the history of the discipline by concentrating exclusively on 'scientific' methodology. Their underlying counter argument is that intellectual histories provide the necessary reference and justification for research agendas, whether these are defences of, or challenges to, orthodoxy. From this they note that for as long as there is a variety of political science orientations there will also be a variety of disciplinary histories (Dryzek and Leonard 1995, 36). But by what criteria can we distinguish between histories?

Dryzek and Leonard maintain that the primary focus of disciplinary histories should be on 'episodes of political science in context.' The basis for explaining and evaluating the efforts of practitioners, approaches and methods, theories and research programs, must rest in the question of 'how well they understood and resolved the problems they confronted.' This historical sense can enrich and advance political science on both methodological and theoretical levels. On the methodological level, the efficacy claims of a methodology would have to be sustained historically to the extent that it could demonstrate its capacity to furnish solid analyses of political life in specific contexts. Claims to methodological adequacy would thus require an historical dimension and in the process mitigate those claims that make 'scientific' rigour the sole criterion.

On the theoretical level, and citing the fundamental historicity of political life, Dryzek and Leonard decouple the notion of theoretical development in political science from a scientistic linear progression. The issue of theoretical progress is cast in terms of the aggregation of 'potentially useful research traditions, each of which is contextually constrained in its problem-solving power.' In so far as disciplinary history reveals a varied repertoire of alternative approaches, it can improve the practitioner's ability to make informed contextual choices thus enhancing their own problem setting.

Dryzek and Leonard insist that the evaluation of disciplinary identities is essentially a product of conflict and debate within and across traditions of inquiry. Indeed the relationship between disciplinary history and identity only takes shape as an outcome of contestation. For this very reason they recommend the merits of an engaged pluralism for the discipline's ongoing dynamism. In this sense pluralism is a positive attribute of the discipline's identity and only becomes a problem when it reflects a retreat into indifference (Dryzek and Leonard 1995, 4344; also see Emy and Linklater 1990b).

This perspective provides a more complex window on American political science. Rather than focusing on a singular notion of coherence, it takes serious account of theoretical and methodological pluralism as well as the fundamental historicity of political science. The conceptualisation of identity in terms of contestation opens up a quite different problem domain where once only dissonance was detected. This is a somewhat different image of the American discipline to that invoked in the critical pathology of Australian political studies. Qualified in this manner, American political science can still offer some help for a critical understanding of the Australian discipline.

Again the approach of Dryzek and Leonard is suggestive, especially with its attention to 'episodes of political science in context.' But this approach also requires tweaking for the Australian case, especially because a number of their questions are 'American' questions (see Wæver 1998; Manicas 1991). This insight leads to two considerations that will help to orient the Australian puzzle. 
First, debates about disciplinary identity within American political science are typically pursued with a strong degree of self-referentiality, in part because of the size of the American discipline and the differentiation and complexity this brings. Given this scale, exogenous intellectual inputs tend to be drawn into the system of American political science as 'resources' for innovation and development. ${ }^{3}$ In 'small countries' like Australia however, even minor inputs can become tidal waves that overwhelm rather than enhance. ${ }^{4}$

Second, and turning the first point around, integral to the system of Australian political science is the constant of the 'Great Elsewhere'-Britain, to some extent Europe, but most certainly America. ${ }^{5}$ As a consequence any history of Australian political science is also about a small country's relation to the metropoles at any particular time. Several kinds of distinctive indigenous strategies arise in response to this predicament.

Therefore the 'Australian question' is not so much about competing schools and traditions in political science as about differing strategies in the face of the larger context. This can be referred to as the 'antipodean' paradox of identity that is symptomatic of the wider Australian culture (see Beilharz 1997; Crozier 1999; Lawson 1987). Nevertheless the history of the discipline in Australia is contentious terrain.

\section{From Political Studies to 'Political Science'}

Political science as a distinct academic discipline emerged in Australia after the Second World War. But there is a lineage stretching back into the nineteenth century that can be traced to the appointment of William Hearn to the Professorship in History and Political Economy at the University of Melbourne in 1854. While Hearn published a well received work on The Government of England (1867), the study of politics at Melbourne and indeed at all other Australian universities was simply incidental to courses in law, philosophy and history for the remainder of the nineteenth century. In the years immediately following Australian Federation (1901) there were pleas for the development of social science to critically evaluate the novel nation-building experiment being pursued in the antipodes (Anderson 1912; Irvine 1914; Bourke 1981). During the First World War and after the Workers Education Association developed courses on political affairs and public administration that were linked to university extension programs. At the same time a number of studies were published on Australian political and social development reflecting on future prospects (see Atkinson 1915, 1919, 1920; Mayo 1919; Northcott 1918).

After the First World War programs in political studies were nurtured at the universities in cognate departments, typically History, Law and Economics. Courses in political studies were offered in History at Tasmania and Queensland and in History and Economics at the University of Western Australia. A program in political philosophy and modern political thought was created at Melbourne in 1933 jointly housed by History and Philosophy. This

\footnotetext{
${ }^{3}$ This is not to underplay the profound influence of German-trained figures and German thought in the origins and development of American political science (see Gunnell 1993).

${ }^{4}$ Another side to this issue of scale is the observation that there appears to be far greater chances for a reformist social science to make an impact in a small country compared to a large (see Davies 1985, 246-247; Seidelman 1985).

${ }^{5}$ The sense of the Great Elsewhere can also be experienced in the metropole. For example, Economics forms a Great Elsewhere for many American political scientists.
} 
became the Department of Political Science in 1939 though a foundation professor was not appointed for another ten years. A new Department of Political Science and History was set up at Adelaide in 1934 though history remained the priority with political science only offered in alternative years due to minimal staff. At Sydney F.A. Bland became the foundation Professor of the Department of Public Administration in the Economics Faculty in 1935. There was also a subject entitled 'political science' offered in Law at Sydney from 1928.

Alongside these tentative developments, several forums and associations concerned with wide-ranging political debate and research emerged in the 1930s against the background of economic depression and the international crisis. The Australian Institute of Political Science (AIPS) was established in 1932 with the aim to 'train young men of ability and character to take an active part in public affairs,' and 'to promote the scientific study of Australian political and economic questions, and to educate public opinion thereon' (AIPS nd; Wilkes 1978; Spann 1955, 87). Drawing together politicians, public servants, academics and community leaders it became a key forum on public affairs in Australia, especially through the pages of its journal The Australian Quarterly and at its annual Summer Schools (the proceedings of which led to a number of significant publications). Small branches of the Royal Institute of International Affairs were founded in the 1920s in Melbourne and Sydney, eventually forming the basis of the Australian Institute of International Affairs (AIIA) in 1933. The AIIA became a central focal point for discussion of foreign affairs as well as developing a large research program (Legge 1999). An Australian affiliate of the British Institute of Public Administration (IPA) was also established during the 1930s focusing specifically on government administration, largely through the efforts of F.A. Bland. Bland had a close knowledge of government administration and had strong views about the conduct of public policy that he readily shared as a robust publicist. He was a regular contributor to AIPS publications, the IPA's Journal of Public Administration and the wider media (Holmes 1999; Maley 1993). The Economic Society of Australia founded in 1925 also promoted discussion on public policy and broader political issues, especially in the pages of its journal, the Economic Record (see Scott 1990). Work on political theory and political philosophy was published regularly in The Australasian Journal of Psychology and Philosophy under the editorship of Professor John Anderson (Philosophy, University of Sydney) from the 1920s onwards. However, it is somewhat indicative that the most influential and enduring study on Australian political culture and nation building to appear in the interwar years was written by the historian W. K. Hancock, simply entitled Australia (1930).

Up until the Second World War, 'political studies' remained largely the province of a small middle class group of (mainly male) academics, students, professionals, businessmen and others who largely knew and interacted with each other in forums like the AIPS (see Foster 1986). In this period there were only six Australia universities each with small student populations. The academic backgrounds of those involved in the university teaching of politics subjects were generally broad Arts often with history, philosophy or law specialisations. The small staff numbers, large undergraduate workloads and lack of funds during the 1930s meant generally that academics had little chance of pursuing substantive research programs. In addition, there were few opportunities for postgraduate studies in Australia, continuing students having to further their studies overseas, mainly in Britain. (North America was beginning to become a destination for postgraduate training but primarily in the fields of economics and education). All of this tempered the growth of political inquiry in the universities, particularly with the Oxbridge connection discounting the pursuit of 'political science' as a distinct academic discipline (Spann 1955,86; Hayward 1991; Vout 1991). The field was thus left to independent organisations like AIPS and the AIIA to 
cultivate debate and promote research on political issues as diverse as foreign relations, economic development, population policy and social provision. Indeed, a recurring appeal echoed in these forums was the call to develop a better understanding of public affairs informed by empirical research that would lead to appropriate public policy. 'Scientific' social research was considered to be the key to deal with broad political questions, a strategy that supposedly would circumvent the sectionalism and class politics of the time (Alomes 1988, 76).

During the Second World War many of those who had been involved with these interwar forums were drawn into the war effort as administrators and researchers. In the context of war mobilisation, the capacity to pursue research-based public policy became a reality with the dramatically increased powers of the federal government. Of note was the Department of Postwar Reconstruction - headed up by the economist H.C. (Nugget) Coombs — which set about developing a comprehensive blueprint for Australia in the transition from war to peace. Under its agency, detailed research was undertaken and implementation programs formulated across a wide range of areas including rural reconstruction, industrial development, education and training, full employment policy and social security (Walter 1988). Looking back to this time, Coombs recalled the faith they placed in the social sciences to inform and steer the building of a new and better Australian nation in the postwar period (Coombs 1981, 199-200; Rowse 1998).

The emergence and expansion of 'political science' as an independent area of study in the Australian academy followed in the wake of this broad vision of postwar reconstruction. On the international level the United Nations Educational, Scientific and Cultural Organization (UNESCO) promoted similar aspirations for the social sciences as part of its broader prospect that a better postwar world could be developed out of the mutual exchange of knowledge and culture between nations (Valderrama 1995,37; Lacoste 1994). Part of the implementation of this program involved the linking of national disciplinary associations into international forums such as the International Sociological Association and the International Political Science Association (IPSA) (Coakley and Trent 2000, 14-18). Indeed, the foundation of the Australasian APSA was driven largely by the UNESCO postwar agenda via IPSA, rather than by local initiative (Aitkin 1985b, 21; Rydon 1985, 2; Rydon 1998). ${ }^{6}$ Nonetheless, political science grew in Australia alongside the increasing demand for university trained personnel in the rapidly expanding career-oriented federal bureaucracy as well as in the wider labour market (see Partridge 1955a, 251). Conversely, the burgeoning range and focus of state activity following the war offered a far wider scope for political analysis well beyond the confines of a narrow institutionalism. Surprisingly the challenge of this wider scope was only taken up slowly and at the edges of the mainstream of political science (Capling \& Galligan 1992, 30-31; see Davies \& Searle 1954b, ix-xi, 1-12).

By the middle of the 1950s the university profile of political science had risen significantly. This can be gauged from the number of professorial chairs and/or independent departments that were established in the years following the war: University of Melbourne (1949), Canberra University College (1949), University of Queensland (1949), University of Adelaide (1951) and University of Tasmania (1956). In 1947 the University of Sydney had widened the reach of its department to Government and Public Administration. During the same period, the Reconstructionists' vision for a national research university was realised in 1946 with the

\footnotetext{
${ }^{6}$ The new Australasian association adopted the title of 'Political Studies' rather than 'Political Science' so that people like Geoffrey Sawer in cognate disciplines could be included in its membership (Rydon 1998).
} 
founding of the Australian National University (ANU) in Canberra. In the field of social sciences this included the establishment of a department of International Relations in 1949 and a department of Political Science in 1951 (Foster and Varghese 1995). The development of political science accelerated towards the end of the 1950s with the significant increase in the size of the Australian tertiary sector generally. From this time the older 'sandstone' universities underwent a new period of growth as new universities were progressively established, expanding the number of universities from seven in the mid 1950s to nineteen by the mid 1970s (Aitkin 1985b, 2-3).

By the early 1980s, political science was firmly established as a distinct academic discipline in the Australian university. From modest and disparate beginnings in the interwar period, political science had become one of the major academic disciplines in the general field of the social sciences and humanities. And since the late 1980s it has established a strong research profile in a highly competitive resources environment (Zetlin 1998, 192, 196). Nonetheless neither a strong sense of the discipline's self-identity nor a widespread self-confidence in its core brief has accompanied the successful institutionalisation of Australian political science.

\section{Surveying Australian Political Science}

There are no systematic histories on the development of political science in Australia, although a number of surveys since the 1950s have attempted to audit the discipline and project future developments. In general terms these surveys highlight a shift in intellectual style from a predominantly British-derived mode to a more diverse culture. This is symptomatic of changes in the academic backgrounds of political science practitioners as it is of the social sciences and humanities more generally in Australia (Goldsworthy 1990). Many of these surveys also evoke the question of political science's distinct identity, with a recurring theme being the problem of 'the derivative,' especially with regard to the character of the Australian polity and the practice of Australian political science. Closer examination of these themes will help to give focus to the 'peculiar' interplay of the distinct and the derivative at work here.

One of the first reviews of political science in postwar Australia was produced by Geoffrey Sawer (1950a, 323), an academic lawyer, for a UNESCO sponsored international survey published in 1950. Sawer observed that Australian political institutions were drawn largely from Britain, arguing that this explained why there were very few studies specifically on the Australian system of government. He recorded certain qualifications to this evaluation noting differences generated by the federal structure of Australian national government as well as some other national peculiarities attributed to geography, climate and economic organisation. Nonetheless he maintained that up until the recent past 'Australian government, like its culture generally, has been derivative in character, and this goes far to explain the relatively backward conditions of academic research, writing and teaching dealing particularly with Australian government.' But Sawer also observed that the coincidence of a growing national consciousness with the synthesizing of imported and local institutions and ideas were all contributing towards the creation of a 'distinctive polity.' This signalled for Sawer a wideopen field for political research, offering possibilities for both pioneering studies and the generation of 'classics' (compare Partridge 1955a, 246-248).

Sawer's conclusion can be considered symptomatic of the enthusiasm for social research that marked the immediate postwar period. The federal government's establishment of a national research university, the ANU, in 1946 was a concrete expression of this enthusiasm while at 
the same time it was a recognition of the extremely limited research capacities of the older Australian universities. In addition, Sawer describes the state of research and teaching as 'backward,' and that this was an outcome of the derivative culture. It is not immediately clear what criteria he is using to make this judgement. If he was comparing research output to Britain or the United States, then there can be no doubt that he was correct in relative and absolute terms. At the time all Australian universities were basically state-funded institutions, resources were meagre, and academic staff were weighed down by large undergraduate teaching responsibilities. If however he was referring to the sophistication of analysis of the Australian polity then certain qualifications need to be considered.

Sawer's description of Australian culture tout court as derivative is misleading, especially with regard to social research. For example, in the interwar period there were several insightful analyses of the peculiarly Australian experiment in nation building that followed in the wake of Federation. Of particular note were W.K. Hancock's Australia (1930) and F.W. Eggleston's State Socialism in Victoria (1931). Both studies employed the term 'state socialism'-albeit somewhat misleadingly - to describe the central and distinctive role of the state in societal mediation in Australia. The work of Hancock and Eggleston can be placed in a tradition, rooted in the nineteenth century Australian colonial experience, which placed a strong analytical focus on state 'developmentalism' and its wider implications (see Capling and Galligan 1992, 24-30). There are certain problems associated with this tradition of analysis (see Connell 1968; Osmond 1985, 163-165; Rowse 1978). Nonetheless it seems ironic that around the same time Sawer was writing his survey, state action in Australia was going into a higher gear, equipped with new Keynesian tools of management. Although American academics had expressed strong interest in the 'Australian experiment' to Sawer during his study tour of the US and Britain in 1949-50, he himself thought of it simply as a version of 'Tory socialism' (Sawer 1950b, 12; also see Sawer 1948, 38). All of this gives some insight into why Sawer did not rate Hancock's Australia as 'political science' per se and why he describes Eggleston's study on 'state socialism' as a 'specialized' work (Sawer 1950a, $324,326)$. This leads to a third observation.

Sawer's survey intimates a particular conception of 'political science' that reveals a certain debt to the pragmatic British tradition of description and analysis, a tradition dominant in the more established disciplines of law and history in the Australian academy at the time. His primary emphasis on political institutions and processes (sans political economy) reflects his own background in the law. This emphasis also suggests a certain eye to contemporaneous developments in American social science (see Cranston 1980). Indeed in his report on his 1949-50 study tour Sawer (1950b, 11) describes 'the Americans' as the leaders in social science research, indicating that he favoured 'the American tendency to accumulation and measurement of facts in the social sciences rather than the European and British tendency toward personal memoir, aesthetic appreciation of character and a priori historicism.' By these criteria the development of Australian political studies was bound to appear 'backward.' From this perspective works focusing on the state would no doubt seem a little passé. Sawer's prognosis of an emerging 'distinctive polity' might have enabled him to project a fertile future for Australian political science research, but at the same time he assumed a burden of the derivative: a notion of political science generated 'elsewhere.'

Sawer's 'burden' has in some ways become indicative of the 'thin' mainstream of political science in Australia. Over thirty years later in a major survey of Australian political science, the general 'idea' of Australian political science conveyed by the editor Don Aitkin (1985a) seemed not all that dissimilar to Sawer's earlier brief outline (also see Aitkin 1984; Tatz \& 
Starr 1982). By the middle 1980s the volume and range of political science research in Australian had proliferated, but the 1985 survey did not really impart a strong sense that a distinctive practice of Australian political science had developed in the interim. Aitkin's closing remarks $(1985 \mathrm{~b}, 32)$ simply touched upon the outgrowth of a pragmatic British legacy: 'Australian social science has been set from the beginning in the empirical tradition, and political science has been that tradition's exemplar.' Aitkin supplemented these remarks with a comment about the need to increase the mathematical and statistical skills in the discipline if its power and professionalism were to grow.

This general portrait generated a degree of heat at the time especially in regard to problems of disciplinary identity. Aside from other shortfalls, the 1985 survey seemed to display little concern about the identity issue, a prominent complaint in its immediate reception (Kemp et al 1985). At one extreme, the survey prompted the declaration that Australian political science was not American enough and therefore incoherent (Sharman 1985, 112). And at another, there was the view that the survey completely ignored 'the vitality and originality of theoretical imaginations in Australian political analysis' (Patience 1985, 108). What is perhaps more apposite to the point is that the 1985 survey merely exemplifies a longstanding tradition of discourse that casts Australian political life (and its analysis) as a practical exercise uncluttered by ideas or debates about fundamental principles. This tradition has been a strong conduit for the theme of 'the derivative.' Although generally assumed in the mainstream, this notion of a politics without ideas has been vigorously challenged at the critical edges of Australian political studies and beyond.

The tradition dates back to at least the 1890 s when a number of observers reported a relative lack of indigenous political thought in Australia. In 1901 the French tourist Alfred Métin (1977) rued the theoretical poverty of Australian political debate compared to Europe, describing Australian politics as 'socialisme sans doctrines' (compare Burgmann 1985, 10; Sawer 2000). This phrase became a kind of mantra conveying a singular message: the practice and study of Australian politics were devoid of 'theory.' James Bryce repeated the impression and W.K. Hancock set it in stone in his Australia. According to Hancock $(1930,69)$ it would be a mistake to think that the Australians have had anything original to contribute to 'the science and art of government.' There are two presumptions transmitted through the tradition here exemplified by Hancock. First, no significant political thought, ideology or ideological contestation has been produced in Australia. Second, when undertaken political thought in Australia has been derivative, unoriginal and by implication inferior (Stokes 1994: 240-1). This sense of deficit construed by Hancock and earlier commentators is repeated by Geoffrey Sawer $(1948,48 ; 1950 a)$ and becomes a staple of mainstream Australian political science (see Loveday 1979; Brugger and Jaensch 1985; Collins 1985; Condren 1985: 37; Emy and Hughes 1988). As a consequence political development and debate in Australia is thus characterised in terms of a pragmatic utilitarianism. It is then presumed that Australian political science simply epitomises this predicament.

\section{Political Science sans idées?}

Geoff Stokes (1994) and James Walter (1988) have produced forceful critiques of this tradition, rallying a good deal of intellectual history and analytical sophistication to debunk its depiction of a 'politics without ideas.' They indicate fundamental problems with the tradition's assumptions focusing on the inadequacy of its conceptual categories and the way these obscure the vital part played by popularisers and bearers of ideas in Australian political culture. 
Stokes takes to task the assertion that Australia lacks its own 'classic' thinker-the equivalent of a Burke, Madison, Calhoun, Paine, Bentham or Locke - who would otherwise give a 'natural' point of reference for political theorising. He also brings in the suggestion that this absence may in part be explained by the lack of an originary event like a revolution in Australia's past. Underlying these assertions is the understanding that if there is an absence of classic thinkers or a revolution then there is bound to be a 'theoretical' deficit in political life. Stokes' intent is not to reveal or uncover either a hitherto hidden Australian classic thinker or an historical moment of political self-creation. To the contrary, he wishes to draw attention to fundamental flaws with the classic thinker/revolution model itself. In particular he shows that the generation and circulation of political ideas that do not sit easily within the model are deemed automatically to be in some manner deficient and in need of intellectual apology. The model thus imputes 'deficit' and 'derivativeness' to Australian political thought merely on the basis that it is different (Stokes 1994, 241-242; also see Melleuish 1993).

Stokes unpacks this problem further by linking it to the notion of classical political theory that claims a particular kind of universal status. This status is commonly asserted by drawing a distinction between 'grand' or universal theorising and political thought addressing concrete political problems. The distinction generates a sharp dichotomy in which the 'universal' is elevated over the particular. Aside from anything else, this manoeuvre pre-empts critical appraisal: if Australia has no grand 'classic' thinkers then any indigenous substantive political thought is immediately devalued. From a critical historicist perspective, Stokes also observes that all political theory is inextricably bound to context, time and place. On the one hand, the elevation of a work to 'universal' or 'classic' status tends to be attributed with extended hindsight by an intellectual or political community. On the other hand, political theorising is done by historically located subjects who work with specific conceptual repertoires and confront particular problematics that arise in their immediate intellectual and social environment. While certain ideas or themes may be considered universalistic this does not detract from the historicity of the process of theorisation (Stokes 1994, 242-244).

Stokes' general argument therefore is that various types of conceptual closures and crude dichotomies have prejudiced and attenuated the study of Australian political thought. From this insight he prompts a shift in orientation, redirecting attention to study of the calibre of work of Australian thinkers no matter whether it be concerned with an avowedly universalistic orientation or with a more specific practical intent. As Stokes demonstrates, the Australian cupboard is hardly bare of examples in either mode (Stokes 1994, 244; compare Emy 1995; also see Melleuish and Stokes 1997).

James Walter makes a similar case against the conventional political science wisdom on Australian political ideas though in a slightly different way. He also rejects the search for 'classic' thinkers and great traditions, and resets the task within a specific conception of political culture. This conception is concerned precisely with ideas - social meanings - in contention. Walter wishes to sensitise analysis to the way political argument and debate is charged with, or at least informed by, fundamental notions about what Australian society is or ought to be. The political culture thus emerges out of conflicting claims articulated by political intellectuals. In this sense the work of those who take it upon themselves to construe the meanings of shared social life can be examined as constitutive sources of the political culture. The role played by intellectuals in Australian political life, paying particular attention to the competing explanations of the social world, can thus be identified as developments in political thought (Walter 1988: 237-243). Walter illustrates his approach and the rich quarries 
it can unearth with a detailed study of the Australian debates on reconstruction after World War Two-a period during which Geoffrey Sawer was reporting on the supposed dearth of Australian political thought.

The discrepancy between more recent critical research and earlier dismissals of Australian political thought cannot be entirely explained simply in terms of inadequate conceptualisation or methodology. There are historical cultural dimensions that also need to be taken into account. Among these is a certain Australian deference to things 'Elsewhere' (see Walter 1996). In the universities this was stimulated by a number of circumstances. First, the intellectual point of reference inside the Australian academy up until the post war expansion was generally back to Britain, rather than between Australian universities. Recruitment of staff from Britain and the exporting of graduate students to Britain for further study emphasised and tended to reproduce this long-standing connection. Second, the heavy burdens of undergraduate teaching meant that 'elsewhere' seemed to be the place where 'real' research was done. This sense was exacerbated by low staff numbers that necessitated academics to teach across a wide range of subjects (Beddie 1989, 34). The rapid expansion of the Australian university sector in the late 1950s and 1960s enabled a greater degree of specialisation by individual academics. Nonetheless within a department of political science, for instance, the norm was for a department to have only one specialist in each of its subject areas. There may or may not have been a community of scholars in the specialist area across the other Australian universities. But is was not unusual for the specialist to seek scholarly sustenance 'overseas' - though from the 1960s on this could just as likely be North America as Britain.

Deference to the 'Great Elsewhere' can also be cited in the local interest in the opinion of overseas visitors. James Walter $(1988,268 \mathrm{n} 8)$ points to how the 'extraordinary deference to the presumed 'knowledge' of overseas commentators - from Métin, the Webbs, Bryce and D.H. Lawrence to Otto Niemeyer and Milton Friedman - has shaped the discourse of our selfstyled intellectuals and obscured the nature of indigenous intellectual culture.' He adds that it 'sometimes seems that any tourist can be asked for definitive commentary on Australia!'

This deference is indicative of a broader 'cultural cringe' that has its roots in the history of Australia as a settler society amplified by the country's great geographical distance from the large 'western' metropoles and its relative demographic 'smallness.' But this cringe is Janusfaced: while it often manifests itself in a self-effacing obsequiousness to the Great Elsewhere, it also appears in the form of an illusionary sense of 'completeness.' The self-assertive claims of the latter rest on the assumption that one's own small world is replete and self-contained, in no need of the outside world and its offerings. By so doing it forecloses recognition of its own deficiencies vis-à-vis differentiation, complexity and competencies that comparison might otherwise elicit (Davies 1985; Walter 1999, 30; compare Hume 1991). This Janus-face is crucial: in the case of mainstream Australian political science it delivers both the derivative thesis and its self-sourced local utilitarianism.

\section{Critical Notes from a 'Small Country'}

While this double-sided response to 'smallness' helps to illuminate a kind of 'mainstream' within Australian political studies it is not the whole story. Even a skewed self-understanding does not necessarily preclude the actual practice of a peculiarly Australian style. For instance Hancock's own mode of analysis in his Australia (1930) defied his more general dismissal of a distinctive approach to Australian politics (Melleuish and Stokes 1997, 118-19). But beyond 
this sort of mismatch, there are also examples of a more critically self-reflective style that tends to circumvent the effects of smallness. This also involves looking 'both ways' yet without the debilitating ambivalences of cringe.

In the 1950s and early 1960s several scholars stand out in this regard and of particular note were Alan Davies, Sol Encel, Henry Mayer and P.H. (Perc) Partridge. What marked out this group at the time was their search for an adequate conceptualisation of Australian politics and society drawing on European and American social theory yet driven by an Australian problematic (see Smyth 1994, 200-221; Capling and Galligan 1992, 32-34). It could be argued that this group initiated a critical 'style' in Australian political science without constituting a 'tradition' per se. In later years their primary interests shifted and developed into diverse areas: Davies into psychosocial politics, Encel into sociology, Mayer into media studies and Partridge into education. Nonetheless, each retained a sense that modern societies like Australia are fundamentally problematic and thus necessitate ongoing critical analysis. Consequently, for social science to remain in touch with its own society it needs to continually re-evaluate its conceptual and analytical tools checking for appropriateness and explanatory power. While it might be difficult to maintain that this critical sense forms a 'tradition' in Australian political science, nonetheless it is a constant. It generally finds its contemporaneous feet through a critical engagement of local and imported ideas and trends that avoids the cringe pathologies. The fact of 'smallness' means that its footing is always finely balanced and often tenuous. It has to navigate continually through the perils of the 'small country' condition. On the one hand, the small country is especially threatened by 'great elsewhere' trends and fashions to the extent that even small waves in the metropole can be tsunami at the periphery. On the other hand, the scale of the small country can easily lead to delusions of intellectual self-sufficiency that delimit innovation and creativity to practical local initiative (see Davies 1985; Davidson 2000).

Partridge offers an illustration of the fine line traversed by the critical style. ${ }^{7}$ At the first conference of the Australian APSA in 1957, the main agenda item was the university teaching of political science. Partridge's contribution includes a general overview on the topic as well as detailed attention to the issue of political theory. Initially he outlines what he considered to be the three objectives of political science teaching: first 'to educate students to understand and participate in the political life they share'; second, to train students for vocational reasons; and third, to produce professional political scientists. Of all of these, Partridge considers the first the primary task, indicating the need for a broad curriculum ranging from the nature of politics and modern political institutions to international relations through to a thorough study of political theory. He notes that political theory 'now refers to many different things' and elucidates on the differing forms. Interspersed with references to contemporary American and British literature, Partridge charts the various forms with his customary analytical ease distinguishing between political theory, history of political thought, political philosophy and the technical political-sociological theory.

\footnotetext{
${ }^{7}$ P.H. Partridge originally trained in philosophy at the University of Sydney under Professor John Anderson, graduating in the mid 1930s. He subsequently taught philosophy at Sydney into the 1940s. In 1947 he shifted to the University of Melbourne to head up the Department of Political Science. During his brief time at Melbourne he made a significant impact on students in the Honours school including Henry Mayer and Sol Encel. He returned to Sydney in 1948 to take up the professorial Chair of Government and Public Administration. In 1955 he was appointed Professor of Social Philosophy in the Research School of Social Sciences at the Australian National University where he remained until his retirement. He spent 1939 on study leave mainly at the London School of Economics working with Karl Mannheim (see Partridge 1947).
} 
After considering resource restraints that might restrict offerings, he insists that one specific type of theory is essential: 'the important thing is for us to construct a political theory to teach, one that never loses sight of contemporary political and social conditions and of what social scientists have to say about them; and which employs and weaves together with as much logical skill as we can command, several different levels or "orders" of political argument. The study of the history of ideas and of classical texts can be no substitute for this important contemporary work of critically reformulating political doctrines and ideas' (Partridge 1958, 28). There are hints of contemporaneous debates in American political science in Partridge's discussion (also see Partridge 1955b; Gunnell 1993). At the same time, he remains highly sceptical about both the claims of the new positive theory then gaining wide circulation and the extreme specialisation in American universities.

Inside this consideration on politics as a university subject, Partridge reflects upon the general character of political science. On the one hand he depicts the discipline as 'multi-parasitic,' drawing its sustenance from a number of other social sciences and humanities. According to Partridge, history, philosophy, economics and psychology each has its own distinct body of fundamental technical knowledge whereas political science is thin in this regard. He thus describes political science as a 'secondary or derivative' social science that draws more from these disciplines than they draw from it. On the other hand, he also makes a case for political science as a 'primary subject':

[Political science] tackles problems, which are of central importance for understanding a social system which none of the other subjects does tackle; it tackles them in ways and for purposes the other subjects ignore or slur. No other subject teaches the careful, scholarly, comparative study of political institutions and processes; certainly no other subject studies as special problems the connection between the structure and functioning of institutions or other formations. And turning to the other, the theoretical "face" of the subject, of course no other subject is concerned with any of the different sorts of theory I have distinguished. Actually, in trying to link together, and to operate with, the several kinds and levels of social thinking, the political scientist is doing something that puts him [sic] in a distinctive position among social scientists. This arises partly from the nature of political activity (or, more accurately, the nature of many of the issues that are characteristic of political activity); the result being that you have in political science an activity of synthesizing to which there is nothing quite comparable in any of the other social sciences. In that sense, political science is more than parasitic: though it borrows material from many fields, it does so for the purpose of dealing with problems which are quite fundamental for the understanding of the working of modern social systems (Partridge 1958, 29-30).

Partridge's conception impresses high social theoretical expectations on the development of political science. At the same time, it is earthed by an abiding concern to analyse and understand the realities of contemporary social life. Directly or indirectly, Partridge's sense of political science can be seen to have touched the perspective of his younger contemporaries like Davies, Encel and Mayer (Davies 1958; Encel 1960, 1962, 1999; Kamenka 1989; Mayer 1956, 1958, 1989; Rigby 1985; Rydon 1985, 1998; Walter 1999, 24-25). The idea that this synthetic skill could be passed on to political science students in their fourth year Honours may have been just a little ambitious on Partridge's part (see Beddie 1958). Equally if he was suggesting that a political theory could be construed that would form an uncontested core for pedagogical purposes then he would also be overplaying his hand (see Beddie 1989).

However these are lesser issues to the main point. This resides in Partridge's general conception of the task of political science. Here he recommends a practice of political science that is neither intellectually deferential nor isolationist vis-à-vis both the other social sciences 
and the Great Elsewhere. The prime duty is to generate understanding of the social world we inhabit critically drawing on all the analytical capacities and conceptual resources available (also see Partridge 1960,112-113). This is a disposition that is not interested in the 'illusions' of deficit or of completeness. It is a hard row to hoe in a small country context and is difficult to maintain consistently over time. In this sense it is more normative than programmatic for research, and is vitalised and revitalised by the experience of smallness. The tourist from the Great Elsewhere often misses the gist for one needs to be able to see both ways simultaneously. For political science research this disposition thus offers, among other things, a critical eye not just on the small country but also on the myopias of the metropole. This is perhaps a small lesson for future research in (and on) Australian political science.

\section{Conclusion}

Political science emerged as a distinct academic discipline in the post war period in Australia (as it did in a number of other countries). Its prewar antecedents were in a number of independent associations as well as in political studies programs hosted in cognate university departments. These precursors bequeathed certain academic approaches and modes to the discipline, especially from History and Law. But it was also nurtured by the postwar optimism in the potency of the social sciences. A key source of this optimism had been the experience of war mobilisation in which social scientific research and public policy had worked in tandem. These varied origins provided a diverse range of approaches and traditions that could be utilised in the study of politics. But they also set up certain tensions within the fledgling discipline that remain to this day, particularly in regard to its disciplinary identity. Is it a social science or a part of the humanities, and what is its distinctive problem domain?

In general a discipline defines itself through a process of differentiation: 'We study these specific problems in this particular way and not those problems in that way.' It is a process of self-definition through the differentiation of one's own practices from other disciplines. In the case of Australian political science its pedigree and its context complicates this process in distinctive ways. The 'American' critique of the Australian discipline bypasses these complications. Its response is that the way to practice political science as a distinct discipline in Australia is to mimic American political science (especially whatever its current orthodoxy seems to be). Here distinctiveness is collapsed into a fanciful image of 'the discipline,' seemingly unaware of the critical research, in America and elsewhere, on the history and sociology of political science in its various contexts, national and international. In this sense, the 'American' critique is more an example of the dual perils of smallness than a lead for analysis. By contrast, confronting the complications of pedigree and context opens up the possibility for a better understanding of past practices, the limitations and innovations. Such an understanding does not automatically deliver disciplinary identity. However it does impress the need for a more complex notion of identity. From this perspective, Australian political science may indeed be problematic but this may no longer appear to be such a bad thing.

\section{REFERENCES}

Aitkin, D. 1984. 'Australia.' In Political Science in Asia and the Pacific, ed. Takeo Uchida. Bangkok: UNESCO, 307-350.

Aitkin, D., ed. 1985a. Surveys of Australian Political Science, Sydney: George Allen and Unwin. 
Aitkin, D. 1985b. 'Political Science in Australia: Development and Situation.' In Aitkin 1985a, 1-35.

Alomes, S. 1988. 'Intellectuals as Publicists 1920s to 1940s.'In Head and Walter 1988, 70-87. Anderson, F. 1912. 'Sociology in Australia: A Plea for its Teaching.' Reprinted in Social Horizons 1943 July, 16-20.

Atkinson, M. et al., eds. 1915. National Efficiency. Melbourne: Victorian Railways Printing. Atkinson, M. 1919. The New Social Order. Sydney: WEA.

Atkinson, M., ed., 1920. Australia: Economic and Political Studies. Melbourne: Macmillan.

AIPS [Australian Institute of Political Science]. nd (1930s). \{Directors and Objects\}, AIPS Archive, Mitchell Library, Sydney, ML MSS 1835 / BoxY12904.

Beddie, B. 1958. 'A Comment on Professor Partridge's Paper.' The Australian Journal of Politics and History IV(1): 31-36.

Beddie, B. 1989. 'Thirty Years On: Reflections on a Debate.' Political Theory Newsletter 1(1): 33-39.

Beilharz, P. 1997. Imagining the Antipodes: Culture, Theory and the Visual in the Work of Bernard Smith. Cambridge: Cambridge University Press.

Bourke, H. 1981. 'Sociology and the Social Sciences in Australia, 1912-1928.' Australian and New Zealand Journal of Sociology 17(1): 26-35.

Bourke, H. 1988. 'Social Scientists as Intellectuals: From the First World War to the Depression.' In Head and Walter 1988, 47-69.

Brown, N. 1995. Governing Prosperity: Social change and social analysis in Australia in the 1950s. Cambridge: Cambridge University Press.

Brown, N. 1997. " "A sense of number and reality": economics and government in Australia 1920-1950.' Economy and Society 26(2): 233-256.

Brugger, B. and D. Jaensch. 1985. Australian Politics: Theory and Practice. Sydney: Allen \& Unwin.

Burgmann, V. 1985. 'In Our Time': Socialism and the Rise of Labor, 1885-1905. North Sydney: George Allen \& Unwin.

Capling, A. and B. Galligan. 1992. Beyond the Protective State: The political economy of Australia's manufacturing industry policy. Cambridge: Cambridge University Press.

Coakley, J. and J. Trent. 2000. History of the International Political Science Association 1949-1999. Dublin: International Political Science Association.

Collins, H. 1985. 'Political Ideology in Australia: The Distinctiveness of a Benthamite Society.' Daedalus 114(1): 147-169.

Condren, C. 1985. 'Political Theory.' In Aitkin 1985a, 36-85.

Connell, R.W. 1968. 'Images of Australia.' Quadrant 12 (March-April): 9-19.

Coombs, H.C. 1981. Trial Balance. Melbourne: Macmillan.

Cranston, R. 1980. "'Lawyer in the Social Sciences"-Geoffrey Sawer.' Federal Law Review 11: 261-270.

Crozier, M. 1999. 'Antipodean Sensibilities.' In After the Garden? ed. Michael Crozier, special issue, South Atlantic Quarterly 98(4): 839-859.

Crozier, M. 2000. 'Society Economized: T.R. Ashworth and the History of the Social Sciences in Australia.' \{manuscript\}.

Davidson, A. 2000. Interview with author, 1 May.

Davies, A. and G. Searle, eds. 1954a. Policies for Progress: Essays in Australian Politics. Melbourne: F.W. Cheshire.

Davies, A. and G. Searle. 1954b. 'Introduction,' and 'The Background of Current Politics.' In Davies and Searle 1954a, vii-xv, 1-12.

Davies, A.F. 1958. Australian Democracy: An Introduction to the Political System. Melbourne: Longman. 
Davies, A. 1985. 'Small Country Blues.' Meanjin 44(2): 243-252.

Dryzek, J. S. and S.T. Leonard. 1995. 'History and Discipline in Political Science.' In Easton, Gunnell and Stein 1995, 27-48.

Easton, D. 1968. 'Political Science.' In International Encyclopedia of the Social Sciences, vol.12, ed. David L. Sills, New York: Macmillan \& the Free Press, 282-298.

Easton, D., J. G. Gunnell and L. Graziano, eds. 1991. The Development of Political Science: A Comparative Study. London and New York: Routledge.

Easton, D., J. G. Gunnell and M. B. Stein, eds. 1995. Regime and Discipline: Democracy and the Development of Political Science. Ann Arbor: The University of Michigan.

Emy, H. and O. Hughes. 1988. Australian Politics: Realities in Conflict. South Melbourne Macmillan, 23-64.

Emy, H. and A. Linklater, eds. 1990a. New Horizons in Politics: Essays with an Australian Focus. Sydney: Allen \& Unwin.

Emy, H. and A. Linklater. 1990b. 'Introduction: Departures and Reappraisals in Politics.' In Emy and Linklater 1990a, 1-22.

Emy, H. 1995. 'Stokes on Australian Political Thought: A Critical Appreciation.' Australian Journal of Political Science 30(2): 335-341.

Encel, S. 1960. 'The Concept of the State in Australian Politics.' The Australian Journal of Politics and History VI(1): 62-76.

Encel, S. 1962. Cabinet Government in Australia. Parkville: Melbourne University Press.

Encel, S. 1999. Interview with author, 27 September.

Farr, J. and R. Seidelman, eds. 1993. Discipline and History: Political Science in the United States. Ann Arbor: University of Michigan.

Farr, J., J. S. Dryzek and S. T. Leonard, eds. 1995. Political Science in History: Research Programs and Political Traditions. Cambridge: Cambridge University Press.

Fleming, G.A. (1995), The Early Years of the Australian Economics Community. Working Papers in Economic History, ANU, no.183, March.

Foster, L. 1986. High Hopes: The Men and Motives of the Australian Round Table. Carlton: Melbourne University Press.

Foster, S.G. and M. Varghese 1996. The Making of the Australian National University. St. Leonards NSW: Allen \& Unwin.

Gunnell, J.G. 1993. The Descent of Political Theory: The Genealogy of an American Vocation. Chicago and London: The University of Chicago Press.

Goldsworthy, D. 1990. 'Australian Political Science in the Age of Accountability.' In Emy and Linklater 1990a, 23-42.

Hancock, W.K. 1930. Australia. London: Benn.

Hayward, J. 1991. 'Cultural and contextual constraints upon the development of political science in Great Britain.' In Easton, Gunnell and Graziano 1991, 95-107.

Head, B. and J. Walter, eds. 1988. Intellectual Movements and Australian Society. Melbourne: Oxford University Press.

Holmes, J. 1999. Interview with author, 6 May.

Hume, L.J. 1991. 'Another Look at the Cultural Cringe.' Political Theory Newsletter 3(1): 136.

Irvine, R.F. 1914. The Place of the Social Sciences in a Modern University. Sydney: Angus and Robertson.

Kamenka, E. 1989. 'Emeritus Professor P.H. Partridge (1910-1988).' Political Theory Newsletter 1(1): 54-56.

Kemp, D., E. Thompson, A. Patience, M. Sawer and C. Sharman 1985. 'Review Symposium' on Aitkin 1985a. In Politics 20(2): 103-112.

Lacoste, M. C. 1994. The Story Of A Grand Design: UNESCO 1946-1993. Paris: UNESCO. 
Lawson, S. 1987. The Archibald Paradox: A Strange Case of Authorship. Ringwood VIC: Penguin.

Legge, J. D. 1999. Australian Outlook: A History of the Australian Institute of International Affairs. St. Leonards NSW: Allen \& Unwin.

Loveday, P. 1979. ' Australian Political Thought.' In The Pieces of Politics, ed. R. Lucy, $2^{\text {nd }}$ edition, Melbourne: Macmillan, 2-28.

Maley, W. 1993. 'The Political Philosophy of F.A. Bland.' Political Theory Newsletter 5(1): 25-38.

Manicas, P.T. 1991. 'The Social Science Disciplines: The American Model.' In Wagner, Wittrock and Whitley 1991, 45-71.

Mayer, H. 1956. 'Some Conceptions of the Australian Party System 1910-1950.' Historical Studies: Australia and New Zealand 7(27): 253-270.

Mayer, H. 1958. 'Introduction.' Studies in Australian Politics: Aaron Wildavsky, The 1926 Referendum; Dagmar Carboch, The Fall of the Bruce-Page Government. Melbourne: F.W. Cheshire.

Mayer, H. 1989. 'Partridge: A Personal Appreciation.' Political Theory Newsletter 1(1): 57. Mayo, E. 1919. Democracy and Freedom. Melbourne: Macmillan.

Melleuish, G. 1993. 'Why Australian Political Thought?' Political Theory Newsletter 5(1): 34.

Melleuish, G. and G. Stokes. 1997. 'Australian political thought.' In Creating Australia: Changing Australian history, ed. W. Hudson and G. Bolton. St Leonards NSW: Allen \& Unwin, 111-121.

Métin, A. [1901] 1977. Socialism Without Doctrine. Trans. of Le Socialisme sans Doctrines (Paris 1901) by Russel Ward. Sydney: Alternative Publishing Co-operative.

Northcott, C. H. 1918. Australian Social Development. New York: Columbia University Press.

Osmond, W. 1985. Frederic Eggleston: An Intellectual in Australian Politics. Sydney: Allen \& Unwin.

Partridge, P.H. 1947. Letter to Registrar, University of Sydney, 28 July 1947, application for Chair of Government and Public Administration. 3pp, Registrar's Correspondence, University of Sydney Archive, Fisher Library.

Partridge, P.H. 1955a 'Teaching and Research in the Social Sciences at Australian Universities.' International Social Science Bulletin VII(2): 245-251.

Partridge, P.H. 1955b. 'Value Judgements and the Social Sciences.' The Australian Journal of Politics and History I(1): 210-222.

Partridge, P.H. 1958. 'Politics as a University Subject.' The Australian Journal of Politics and History IV(1): 19-30.

Partridge, P.H. 1960. 'Lament for Social Philosophy.' The Australian Journal of Politics and History VI(1): 109-113.

Patience, A. 1985. 'Review Symposium,' on Aitkin 1985a. In Politics 20(2): 107-109.

Rigby, T.H. 1985. 'Henry in the Eyes of Fellow Students.' Politics 20(2): 5.

Rowse, T. 1978. Australian Liberalism and National Character. Melbourne: Kibble Books.

Rowse, T. 1998. 'The People and their Experts: A War-inspired Civics for H.C. Coombs.' Labour History 74: 70-87.

Rydon, J. 1985. 'Henry Mayer and Australian Political Studies.' Politics 20(2): 1-4.

Rydon, J. 1998. Interviews with author, 24 April, 1 May.

Sawer, G. 1948. Australian Government Today. Carlton: Melbourne University Press.

Sawer, G. 1950a. 'Political Science in Australia.' In Contemporary Political Science. Paris: UNESCO, 323-326. 
Sawer, G. 1950b. 'Tour of USA and Britain. Report by G. Sawer.' May, 13pp, papers of Interim Council of the Australian National University (1946-1951), National Archives of Australia, Canberra, NAA CP487/2, Item 16.

Sawer, M. 2000. 'The Ethical State: Social Liberalism and the Critique of Contract.' Australian Historical Studies 31(114): 67-90.

Scott, R.H. 1990. The Economic Society of Australia, Its History: 1925-1985. Canberra: Economic Society of Australia.

Seidelman, R. 1985. Disenchanted Realists: Political Science and the American Crisis, 18841984. Albany NY: State University of New York Press.

Sharman, C. 1985. 'Review Symposium,' on Aitkin 1985a. In Politics 20(2): 111-112.

Smyth, P. 1994. Australian Social Policy: The Keynesian Chapter. Sydney: University of New South Wales Press.

Spann, R.N. 1955. 'Political Science in Australia.' The Australian Journal of Politics and History 1(1): 86-97.

Spann, R.N., ed. 1958. 'Political Science in Australian Universities: The Australian Political Studies Conference, Canberra, August 1957,' special issue of The Australian Journal of Politics and History IV(1).

Stokes, G. 1994. 'Conceptions of Australian Political Thought: A Methodological Critique.' Australian Journal of Political Science 29(2): 240-258.

Tatz, C. and G. Starr (1982), 'Australia,' in William G. Andrews, ed., International Handbook of Political Science. Westport CO and London: Greenwood Press, 74-84.

Valderrama, F. 1995. A History of UNESCO. Paris: UNESCO.

Vout, M. 1991. 'Oxford and the Emergence of Political Science in England 1945-1960.' In Wagner, Wittrock and Whitley 1991, 163-191.

Wæver, O. 1998. 'The Sociology of a Not So International Discipline: American and European Developments in International Relations.' International Organization 52(4), 687-727.

Wagner, P., B. Whitley and R. Whitley, eds. 1991. Discourses on Society: The Shaping of the Social Science Disciplines. Sociology of the Sciences, Volume 15, Yearbook 1991. Dordrecht: Kluwer.

Walter, J. 1988. 'Intellectuals and the Political Culture.' In Head and Walter 1988, 237-273.

Walter, J. 1996. Tunnel Vision: The Failure of Political Imagination. Sydney: Allen \& Unwin.

Walter, J. 1999. ' Bureaucracy and Democracy in the American Century: A.F. Davies on Administration and the "Knowledgeable Society".' Australian Journal of Public Administration 58(1): 23-32.

Wilkes, J. 1978. 'In the Beginning...' The Australian Quarterly 50(4): 4-9.

Zetlin, D. 1998. 'Political Science,' in Australian Research Council, Discipline Research Strategies, Challenges for the Social Science and Australia. Volume 1, prepared by the Academy of the Social Science in Australia. Canberra: Australian Government Publishing Services, 189-200. 


\section{University Library}

\section{- M M I E R R A A gateway to Melbourne's research publications}

Minerva Access is the Institutional Repository of The University of Melbourne

Author/s:

CROZIER, MICHAEL

Title:

A problematic discipline: the identity of Australian political studies

Date:

2001

Citation:

Crozier, M. (2001). A problematic discipline: the identity of Australian political studies. Australian Journal of Political Science, 36(1), 7-26.

Publication Status:

Published

Persistent Link:

http://hdl.handle.net/11343/34424 